International Journal of English Literature and Social Sciences
Vol-6, Issue-1; Jan-Feb, 2021

\title{
Linguistic Aspects of Translation Between French and English
}

\section{Adnan Jabar Hamid}

\author{
Al Turath University College, Baghdad, Iraq
}

Received: 26 Oct 2020; Received in revised form: 18 Jan 2021; Accepted: 09 Feb 2021; Available online: 27 Feb 2021

(C)2021 The Author(s). Published by Infogain Publication. This is an open access article under the CC BY license

(https://creativecommons.org/licenses/by/4.0/).

\begin{abstract}
Translation is the transfer of a message from one language - which can be referred to as the source language - into another language, designated as the target language.

Whether translators are born or can be trained is an open-ended question. However, by observing and being aware of certain facts, one can go beyond the glaring erroneous translations that result from a lack of experience or sometimes even from a lack of time.

Avoiding cultural bias and paraphrasing are important tools for a translator. However, linguistic differences between both languages make it important and necessary to be prudent and diligent while translating.
\end{abstract}

A range of differences between the two languages - seemingly simple aspects like the use of punctuation, capitalization or more prevalent aspects like semantics - all pose a challenge to translators.

This paper treats the challenges that translators could face in their activity due to certain linguistic elements.

Keywords - source language, target language, translator, linguistic elements.

\section{INTRODUCTION}

When it comes to erroneous translations, cultural bias could be the largest cause of errors in translation. Linguistic rules of the mother tongue, acquired in childhood, tend to be innate within us and its influence can be seen during the acquisition of a foreign language even after the language has been mastered. However, with practice and training these errors can be avoided. Accuracy and economy are the signs of a good translation. However, an error-free and precise translation depends on many factors. There are different linguistic aspects between English and French and one needs to be prudent while translating between the two languages.

In order to ensure accurate translation, a good understanding of linguistic aspects: grammar of both languages, semantics even stylistics. Translation essentially involves two steps: (a) comprehension of the source language and (b) expression in the target language. The difficulty for the translator lies in mastering these two steps.

\section{EFFECTIVE USE OF ARTICLES AND PREPOSITIONS}

The efficient use of articles and prepositions - in spite of the fact thatthey belong to a closed list - require linguistic observation and reflection apart from advanced use of the language. A weak understanding of the use of articles is a regular problem faced by translators.

A. Definite Articles: Definite articles can pose a problem if the translator does not understand whether the definite article is referring to aspecific noun or a noun in general, in the source text. In the sentence, "Il aimealler à l'église", the word 'église' could be generic, "He likes to go to church" or actual"He likes to go to the church".

B. Indefinite Articles: Indefinite articles could also be a challenge because there are instances where the indefinite article is carried over into the English version in translation 
and there are instances where the article is left out. Let us look at examples, "M. Dupont a des voitures" can be translated as, "Mr Dupont has cars" but the sentence "Marie a unevoiture" can be translated as, "Marie has a car".

C. Partitive Articles: This type of confusion appears while translating sentences with partitive article. Like in the sentence, "Je vaisboire du café" where the partitive article could be transferred into the English version, "I am going to drink some coffee". But in the sentence, "Pour le déjeunernormalement, je prends $d u$ riz" is translated as, "For lunch, I normally eat rice".

D. Confusion Among Articles: To add to this, there is confusion among the articles themselves, given that different types of articles can have the same form. For example, 'des' can be indefinite or partitive article. The sentence, "J'ai des croissants" could be translated as, "I have croissants" or "I have some croissants". Context can eliminate ambiguity in such situations.

E. Exceptional Form While Using Articles: While translating towards French, these problems can be accentuated by the tendency of articles to undergo a change in the presence of adjectives appearing before the noun or in the case of sentence negation. Take the sentence, "Je mange de la viande". The partitive article in this sentence changes in the case of negation: "Je ne mange pas de viande". The same is seen in the case of the indefinite article, "Marie a des amies" but in case of negation the sentence would be, "Marie n'a pas d'amies". This however does not happen in the case of 'être' verb. Look at the example: "C'est de la viande". The partitive article stays the same in negation when the verb is 'être'; "Cen'est pas de la viande". And also the same for the indefinite article, "C'estunefille" where the indefinite article remains the same in negation, "Cen'est pas unefille".

When an adjective appears before the noun, the indefinite article undergoes a similar change. The indefinite article 'des' becomes 'de'. "Je passe des moments à la plage". If we place the adjective 'bons' before the noun, the article 'des' changes to 'de'; “Je passe de bons moments à la plage".

Incorrect translations could also result from a misunderstanding of prepositions. In the following sentence, "J'ai des nouvelles de Lyon", the preposition 'de' before the word 'Lyon', could confuse the translator. It could be that the speaker has news about the city of Lyon or it could be that there is news about someone who lives in Lyon.

\section{INCOMPATIBILITY OF ADJECTIVES}

Adjectives in a language don't always have an equivalent in another language. Equivalents in French and English can vary in their nuances or the mental images they evoke. Take the adjective 'souriant'. Larousse suggests synonyms like 'smiling', 'beaming' and 'cheerful'. But none of these words evoke, in a single word, all the images that the word 'souriant' evokes. The website recommends 'a bright future' as a translation for 'un avenirsouriant'. There are other adjectives like 'mondain', 'manqué' etc. In the sentence, 'Le gâteauest manqué", the adjective 'manqué' means 'spoiled'. But in this sentence, "Natacha a choisi un métier technique, maisc'estuneoratricemanquée", the adjective 'manqué' cannot be translated by an adjective; "Natasha opted for a technical job but she would have been a good public speaker".

In French, adjectives may have more than one signified, which could cause confusion for the translator. Take the example of the word 'important' in French.This word can mean 'necessary', 'primary'etc.But this word cannot be translated as 'important' in English.In Englishthis adjective is used to qualify nouns in a more positive manner. For example, "He is an important part of this investigation" or the sentence, "Objectivity is an important trait for linguists". But in the sentence, "Il a subi des pertesimportantesdansses affaires" the word 'importantes' doesn't mean 'important' in English but rather 'considerable', "He suffered considerable losses in his business".

\section{INCOMPATIBILITY OF VERBS}

Incompatibility exists between verbs also. For example, the verb 'avoir' in French can be considered as the equivalent of the verb 'to have' in English. For example, "I have a pen" can be translated as, "J'ai un stylo". However, there are plenty of examples where the verbs 'avoir' and 'to have' are not in correlation. For example, the sentence "J'aisoif", cannot be translated into English as "I have thirst"but rather by the sentence, "I am thirsty". Consider other examples to elaborate this fact: "I have breakfast" which could be translated as "Je prends le petit-déjeuner". Or the sentence "I have fun at parties" translated as "Je m'amuse aux soirées".

\section{POOR COMPREHENSION IN THE CASE OF COMPOUND SENTENCES}

Compound sentences can cause the translator to lose track of meaning, which could prevent an efficient translation. Let us 
analyse an example, "Pollution has serious effects on health and environment which transforms the Earth's climate and ecosystem, resulting in unknown diseases". A version in French couldbe, "La pollution a des effets importants sur la santé et l'environnement qui transforme le climat de la Terre et son écosystème, en entraînant l'apparition de maladies inconnues". The relative pronoun 'qui' in the above sentence replaces the subject 'la pollution' but it can be misconstrued as a replacement for the word 'l'environnement'.

In order to avoid confusion with compound sentences, it is possible to divide the sentence into two or even explicitly draft the sentence. "La pollution a des effets importants sur la santé et l'environnement. Cela transforme le climat de la Terre et son écosystème, en entraînant l'apparition de maladies inconnues". It isalso possible to translate with a compound sentence, "La pollution a des effets importants sur la santé et l'environnement, ce qui transforme le climat de la Terre et son écosystème, en entraînant l'apparition de maladies inconnues".

\section{IDEAS WITHOUT PARALLEL IN THE TARGET LANGUAGE}

A primary challenge for the translator is to transfer ideas which are difficult to explain in the target language due to cultural differences. The word 'dépaysement'- a feeling of restlessness one feels when far from one's own country - is difficult to transmit into English. It is a sort of disorientation or cultural shock. The word 'dépaysement' is used when the current environment becomes too much and there is a strong desire for a change. Another example, 'esprit de l'escalier' is the feeling of having the perfect repartee but only when it is too late.

In such cases, the translation could lead to amplification: situation where the target language uses more words than the source language to express the same idea. (Vinay \& Darbelnet : 1972).Consider the word 'clockwise' in English, "Close the water tank by tightening the tank cap clockwise by hand"which can be translated as, "Fermezhermétiquement le réservoird'eau en serrant à la main le couvercle du réservoirdans le sens des aiguilles d'unemontre". Amplification would result in the TL version being longer than the SL text.

The translation of an English text is often longer than the French version. The reasons for this are many among which are : a lack of apposition in French to show possession ('John's bicycle' becomes 'le vélo de John'), usage of a preposition to form compound words ('pocket money' becomes 'argent de poche'), usage of a determiner in French for nouns"I like chocolate" is translated as, "j'aime le chocolat" etc.

\section{LITERAL TRANSLATION}

According to Peter Newmark, professor of translation, each translation must be literal except if it leads to an error. However, literal translation could lead to errors if the translator is not careful: (Newmark: 1988)

A. Improper Particularisation: Words which, despite their appearances, do not add value to the translation in terms of information. The translation of such words must be avoided. (Vinay \& Darbelnet : 1972). "C'est une bonne idée et $j$ 'aime celle de Paul aussi". "That's a good idea and I like the one of Paul also". The demonstrative pronoun 'celle' adds no value to contextin the English version. A pragmatic translation would be "That's a good idea and I like Paul's also".

B. False Friends: These are words which, seem to have the same meaning in both languages primarily because they have the same origin, but which in fact, have different meanings. (Vinay \& Darbelnet : 1972). This is another possibility in the errors arising from literal translation, which are to be completely avoided. "Soisgentil avec Marie;elleest sensible"». Here, 'sensible' means 'sensitive' - "Be kind to Marie; she is sensitive".

C. Lacuna: A lacuna arises whenever a signified from the SL does not have a common signifier in the TL. For example, the absence of a single word to translate 'shallow' (peuprofond). (Vinay\&Darbelnet : 1972)

\section{OBSERVATION OF LINGUISTIC ELEMENTS IN PRACTICAL TRANSLATIONS}

Accurate translation demands a continuous reading in the two languages by the translator. In order to achieve accuracy in translation, certain steps have to be followed.

A. It is Important, for Example, While Tanslating Figurative Expressions: Animism is the trait of a language which gives the behaviour of people to objects. (Vinay\&Darbelnet : 1972). It cannot be translated as it is. The translation must be natural and culturally well adapted. Take the English sentence, "There is a yawning gap between the rich and the poor in certain countries", which can be translated as, "Il y a un troubéant entre les riches et les pauvresdanscertains pays". 


\section{B. In Effective Translation, Attitude Can be Observed:}

Manner in which language reflects the attitude of the speaker speaking with regard to the subject. (Vinay \& Darbelnet: 1972). "The Honourable prime minister will give a speech now". "Monsieur le premier ministrevaprendre la parole".

C. In Translation One Can Also Observe Connector: Word or group of words which mark the articulation of the statement. For example: en effet, car, comme etc. There is zero connector when the articulation is implicit, for example when 'en effet' is not translated into English. (Vinay \&Darbelnet: 1972). "Elle n'est pas fille unique; en effet, elle a 3 sæurs". "She is not an only child, she has three sisters".

D. One Can See Other Trends in Translation Like Interchange: It is the phenomenon in translation where two signifieds correlate by changing their grammatical category. Example: "He limped across the street". "Il a traversé la rue en boitant". (Vinay\&Darbelnet : 1972).

E. Concentration: term which expresses the concentration of multiple signifieds on a smaller number of signifieds, or even a single one (Vinay \& Darbelnet : 1972). Considert his example, "Nous informerons nos clients à ce sujet au fur et à mesure que l'information sera disponible". "We will provide more information to our clients as it becomes available". ' $A u$ fur et à mesureque' is translated by a single word, 'as' which is concentration.

F. Thematic Structure: a language's tendency to choose from multiple possible structures (Vinay \& Darbelnet: 1972). For example, the preference in English for the passive voice highlights the thematic structure of this language. "I was told that Christmas vacation lasts 2 weeks in this company". "On m'a dit que les vacances de Noël durent 2 semaines dans cette société".

\section{CONCLUSION}

Different types of texts require different skills. An effective cultural understanding would facilitate literary translation while technical knowledge would facilitate technical translation. Traditionally, translators were expected to master the language pairs, update their skills etc.

But in 2014, Mathelinda Nabugodi, in her article quoted Walter Benjamin making reference to his text "The Task of the Translator",

“ $[\ldots]$ tried to conceive translation as a form of art which is interested in everything that happens when one language transfers to another. The primary argument of Benjamin was that the appreciation of art is not concerned with interpretation of its content to extract a moral. Even though art is very important for whoever appreciates it, the primary intention of art is not to inform, instruct or even please anybody. So, if the original text does not exist for the reader, what purpose does the analysis of a translation serve, which is based on this hypothesis" (Nabugodi: 2014, trans. Adnan Jabar Hamid).

Even though this argument seems counter-intuitive, perhaps Benjamin was right to try to establish translation as an art form, because each translation would be useless without its creativity. One must always take into consideration, all the elements related to a text in the SL: the domain to which the text belongs, the presence and clarity of context, the client's expectations etc.

\section{REFERENCES}

[1] Vinay, Jean-Paul \&Jean Darbelnet. Stylistique comparée du français et de l'anglais. Didier, 1972.

[2] Newmark, Peter. A textbook of Translation. Prentice-Hall International, 1988.

[3] Sager, Juan. C and M.J. Hamel,translators. Comparative Stylistics of French and English. ByVinay, Jean-Paul \&JeanDarbelnet, BTL, 1995.

[4] Nabugodi, Mathelinda."Pure Language 2.0: Walter Benjamin's Theory of Language and Translation Technology."Open Humanities Press,2014. http://openhumanitiespress.org/feedback/literature/purelanguage-2-0-walter-benjamins-theory-of-language-andtranslation-technology/

[5] "203 most beautiful untranslatable words [The ultimate list: A - Z]."The Intrepid Guide, 14 Aug 2020.https://www.theintrepidguide.com/untranslatablewords-ultimate-list\#.X8nZltgzbIU

[6] "French idioms by the bushel: 22 deliciously authentic phrases." :Fluent $U$. https://www.fluentu.com/blog/french/french-idioms-2/

[7] "Stylistics." Britannica.https://www.britannica.com/science/st ylistics 